\title{
EFFECT OF WORK-BASED LEARNING MODEL ON STUDENTS' ACHIEVEMENT MOTIVATION
}

\author{
Dwi Agus Sudjimat ${ }^{1}$ and Luchyto Chandra Permadi ${ }^{2}$ \\ ${ }^{1}$ Universitas Negeri Malang, Indonesia \\ ${ }^{2}$ Postgraduate School, Universitas Negeri Malang, Indonesia \\ E-mail: agussudjimat@gmail.com
}

\begin{abstract}
This study determines the effect of the Work-Based Learning (WBL) model on achievement motivation of students in the Study Program of Mechanical Engineering at Vocational High Schools (VHS) compared to the Training Within Industry (TWI) model. This study used a quasi-experimental research method with a factorial design in two groups of XII grade vocational high school students of mechanical engineering. The data in the form of achievement motivation was collected using a questionnaire. The data were analyzed using two way Anova technique with $\alpha$ of 0.05 . The results showed that (1) the students taught using the WBL model had a significantly higher achievement motivation than the achievement motivation of students taught using the TWI model; (2) students with high prior knowledge had a significantly higher achievement motivation than the achievement motivation possessed by students with moderate and low prior knowledge; and (3) there is an interaction between the use of learning models and students' prior knowledge towards students' achievement motivation. The findings indicated that the WBL model has the potential to improve the quality of learning outcomes of vocational education, especially in increasing students' achievement motivation, compared to traditional learning using the TWI model.
\end{abstract}

Keywords: achievement motivation, prior knowledge, work-based learning, training within industry, vocational education

\section{INTRODUCTION}

The characteristics of superior employees of the XXI century that should be produced by vocational education are employees who are competent in their fields and their character in accordance with the demands of the global era. Today, all workplaces are looking for employees who are not only highly skilled but also able to respond to changing complex needs in the contemporary workplace [1], [2]. But in fact, there are still a number of VHS graduates who have not yet got a job. It shows the lack of synchronization between the knowledge taught at VHS with the skills needed in the workplace, in the case of the existence of VHS can not be separated from employment in the workplace [3].

The preparation of superior employees through VHS should be carried out by design, since the design of learning have been aimed to develop the hard skills (cognitive and practical skills) and soft skills, such as integrated employee character values of XXI century [4]. Among the employee character values of XXI century that are important to develop in students are the intrapersonal skills values, which can be assembled in achievement motivation.

Several studies psychologically explain that achievement motivation is considered as desire and encouragement that are in someone to be involved in a task and conducted a task with the best results, which meet certain excellence standards. In this context, McClelland [5] stated that achievement motivation is desire that is in someone who encourages the person to try to reach the standard or measure of excellence. This is consistent with the opinion of Santrock [6] who argued that 
achievement motivation is the desire and encouragement of someone to do something with good results. In fact, achievement motivation can be conisdered as person's tendency to achieve successful or obtain what is the desired final goal, one's involvement in task, someone's expectation to succeed in task they are assigned, and the drive to face obstacles in doing various jobs quickly and precisely [7]. Thus, achievement motivation is driving force for person to progress and succeed based on selfconfidence.

Readiness is an important key before someone enters the workforce [3]. Someone who already has a job readiness will be more successful in pursuing his career. Readiness of work is all the individual conditions that include physical readiness, mental, broad insight and experience and the willingness to perform a job or activity. In addition to these three aspects, one's success towards his work is also supported by his love of work or often referred to as passion. Someone who loves his work will work diligently, passionately, creatively, and not depressed. In preparing the student as a workforce also need to provide motivation to learn that is contained in self and outside students to make changes in behavior. How important to cultivate student learning motivation, because its existence is very meaningful for the act of learning to the goals to be achieved. According to Shani \& Lau [8] work motivation is a set of energetic forces that originates both within as well as beyond an individuals being. A student, who has been motivated to learn something, will try to learn it well and diligently, in the hope of getting good results [3]. Good results will affect the readiness of the student's work. This should be nurtured early, which is to optimize the readiness of work in the field of mechanical engineering expertise.
Someone who has high achievement motivation generally always shows the following characteristics: (a) always wants to find achievements, (b) likes competition, (c) wants to always be excellent, (d) likes realistic challenges, and (e) wants more feedback about successes and failures compared to someone who has low achievement motivation [5]. It was also explained that in high achievement motivation contained aspects of responsibility, risk considerations in the selection of tasks, attention to feedback, creative and innovative thoughts, the desire to be the best, and time to complete tasks. Therefore achievement motivation is very appropriate to be developed in vocational education to obtain superior and highly competitive human resources.

Educational environment takes place and learning process which was experienced by students has big contribution to the development of their achievement motivation. Motivation is the whole process of encouraging/improving one's motives in such a way that he is motivated to do something (behave) with eager to achieve the desired goal in an effort to satisfy his needs [8]. The pleasant environment, nonthreatening learning climate, encouragement and optimism in learning, tend to encourage someone to be interested in learning, have a tolerance to the atmosphere of competition and not worry about failure that will be able to result students to have high achievement motivation. One of learning model that has such characteristics and suitable to be applied in VHS is WBL. Work-Based Learning (WBL) is learning model that deals with all fields of work, learning in workplace and laerning through the work [9]. Within the rather narrow limits of Vocational Education and Ttraining (VET), WBL refers to learning that occurs through 
doing real work, through the production of tangible goods and services, paid and unpaid. In VET, WBL models can also be used to develop the basic work habits, job identity, and specific work competencies. Due to its attractiveness as a form of strong learning, it can also be used for broader educational purposes, for example it is used as a way to motivate the disadvantaged students [10].

According to Abdillah [11], WBL should be used and implemented in vocational schools for several reasons, including (1) WBL offers many opportunities for learning outside traditional learning; (2) WBL arises because of the demand to achieve higher quality, efficiency and linkages between education and work; (3) WBL is needed because of the need to develop student work skills for the future of employment; (4) WBL is needed because of the need for life long education and care education in the workplace; and (5) Siswanto [12] added that WBL impacts positively on the quality of learning. WBL is needed because of the need for career development and professional development. WBL does not always involve the workplace, but can involve a simulated work environment in schools, where skills can be obtained using the concept of service learning. In service learning students are involved in organizing academic activities and designing practical activities provided to meet society needs. Service Learning emphasizes the potential of each student for positive change in society [13] and produces opportunities for joint development of technical, interpretive, and skill aspects [14]. There are two main activities for students who are involved in service learning, they are (a) participate in an organized service activity that meets identified community needs, and (b) reflect on services that are useful to gain further understanding of course content, a broader appreciation of discipline, and an enhanced sense of personal values and civic responsibility [15].

Generally, nowadays the learning characteristics which carried out at VHS are still largely conventional, which are characterized by the use of TWI model 15 [16]. Training Within Industry (TWI) is a model that adopts training methods in industries that has five steps, they are material delivery, demonstration, imitation, practical assignments, and evaluation 2 [17]. Syntax of TWI model indeed relatively simple and easily implemented by vocational teachers on VHS. In addition, among the reasons of teachers who still use the TWI model are because the most important thing for them is to make students understand the competencies and pass the skills competency test, instead of making students able to make certain products that are sold [18]. Compared to other learning models, TWI model has several weaknesses, that are (1) not fully able to equip the ability or skills to deal with crisis situations in the profession, (2) causing students to depend on the teacher, (3) obstructing the development of the ability to cooperate, and (4) does not address complex problems whose reach extends beyond the boundaries of the profession's own field [16].

Besides being influenced by the environment and learning process carried out by the teachers, students' achievement motivation are also influenced by the prior knowledge that they have. Purwanto [7] in his research found that the more familiar students against the prior knowledge, the higher the intrinsic motivation of students in the lesson. This is consistent with the logic of thinking that to understand new material often requires mastery of the material at the 
level below it. That is why Dick \& Carey [19] stated the importance of learning designers to measure prior knowledge of prospective users of learning products as a result of their design before determining the learning materials and strategies in their learning design. Referring to the explanation, this study had three objectives that wanted to be created, that were (1) to find out the differences in achievement motivation between students group who taught by using WBL model with the concept of service learning and students group who taught by using TWI model; (2) to find out differences in achievement motivation between students group who have high, medium, and low prior knowledge; and (3) to find out the interaction between the use of learning models and prior knowledge of students against the achievement motivation.

\section{METHOD}

This research was conducted using a quasi-experimental method with a $2 \times 3$ factorial design, where two columns state the independent variable in the form of a learning model consisting of the WBL model with service learning and the TWI model, while the three rows state the moderator variable in the form of students' prior knowledge consisting of three levels, namely high, medium, and low. The subjects of this study consisted of two classes, namely class XII-ME1 consisting of 30 students and XII-ME2 consisting of 26 students in State VHS 6 Malang in the Mechanical Engineering Program. Randomly, students in class XII-ME1 are assigned as the control class taught using the TWI model, and students in XII-ME2 are assigned as the experimental class taught using the WBL model in Machining Lathe
Subjects with complex turning material. The dependent variable was students' achievement motivation. This experimental study was conducted for five meetings where each meeting was $7 \times 45$ minutes.

The research data in the form of student achievement motivation were collected using questionnaire which developed in reference to the achievement motivation theory proposed by McClelland [5]. While prior knowledge data of students was collected using multiple choice written test developed based on syllabus of machining lathe subject on complex turning material. Before being used, the two instruments were validated by experts and field tested to determine their validity and reliability.

Validation analysis of instruments based on trial data was done using the Product Moment Pearson formula [20]. Based on the provisions given by Sarjono \& Julianti [20], the following results were obtained (1) for the achievement motivation instruments from the 35 items analyzed which obtained 30 valid items, and (2) for the prior knowledge instruments from the 30 items analyzed which obtained 27 valid items. Whereas for instrument reliability is calculated based on the Cronbach Alpha formula [20] with a result of 0.744 for achievement motivation instruments, and 0.756 for prior knowledge instruments.

After being tested for requirements, which included normality and homogeneity, then the research data was analyzed using two-way ANOVA analysis techniques.

\section{RESULTS AND DISCUSSION}

The research data in the form of achievement motivation of students from the WBL class and the TWI class are shown in Table 1. While the data on students' 
achievement motivation based on their prior knowledge levels in the two classes are shown in Table 2.

Table 1. Data of Achievement Motivation of Students from the WBL and TWI Class

\begin{tabular}{lllll}
\hline \multicolumn{1}{c}{ Category } & $\mathrm{N}$ & Min & Mean & Max \\
\hline $\begin{array}{l}\text { WBL Class with } \\
\text { service learning }\end{array}$ & 26 & 74.00 & 84.00 & 98.00 \\
TWI Class & 30 & 72.00 & 82.50 & 96.00
\end{tabular}

The test requirements results for achievement motivation and prior knowledge data of students from each WBL and TWI class including normality and homogeneity are shown in Table 3 and Table 4. Table 3 shows that the value of Asymp. Sig. (2-tailed) $>0.05$, it could be concluded that prior knowledge and achievement motivation of students in TWI and WBL with the concept of service learning classes were distributed normally.

Table 2. Data of Achievement Motivation of Students Based on Their Prior Knowledge Levels

\begin{tabular}{ccccccccc}
\hline $\begin{array}{c}\text { Level of } \\
\text { Prior } \\
\text { Knowledge }\end{array}$ & $\mathrm{N}$ & Min & Mean & Max & $\mathrm{N}$ & Min & Mean & Max \\
\cline { 2 - 8 } & 9 & 91.00 & 94.00 & 98.00 & 13 & 85.00 & 90.00 & 96.00 \\
$\begin{array}{c}\text { High Prior } \\
\text { Knowledge } \\
\text { Medium } \\
\text { Prior }\end{array}$ & 11 & 81.00 & 84.00 & 90.00 & 11 & 76.00 & 83.00 & 84.00 \\
$\begin{array}{c}\text { Knowledge } \\
\text { Low Prior }\end{array}$ & 6 & 74.00 & 76.00 & 80.00 & 6 & 72.00 & 74.00 & 75.00 \\
Knowledge & 6 & & & & & & \\
\hline
\end{tabular}

Table 3. The Result of Normality test

\begin{tabular}{lccc}
\hline \multicolumn{1}{c}{ Data tested } & $\begin{array}{c}\text { Asymp. Sig. } \\
\text { (2-tailed) }\end{array}$ & Sig. level & Information \\
\hline Prior Knowledge & 0.172 & 0.05 & Distributed Normally \\
Achievement Motivation & 0.806 & 0.05 & Distributed Normally \\
\hline
\end{tabular}

Table 4. The Results of Homogeneity Test

\begin{tabular}{lccc}
\hline \multicolumn{1}{c}{ Data tested } & Levene statistics & Sig. & Information \\
\hline Prior Knowledge & 0.195 & 0.661 & Homogeneous \\
Achievement Motivation & 0.822 & 0.435 & Homogeneous \\
\hline
\end{tabular}

According to Table 4, it was known that the Sig. $>0.05$, it could be concluded that prior knowledge and achievement motivation of students in TWI and WBL with the concept of service learning classes were homogeneous. Based on Table 3 and Table 4 it could be concluded that the data fulfilled the requirements to be analyzed using the Two Ways Anova analysis technique whose the results were shown in Table 5 .
According to Table 5, could be understood that the p-value (sig.) of each dependent variables test, that were students' achievement motivation, based on the independent variables, moderator variables, and interactions between independent variables and all moderator variables is $<\alpha$ (which was set at 0.05). Based on the students' achievement motivation test, the independent variable of TWI_WBL, obtained p-value (sig.) $<\alpha$ or $0.00<0.05$. 
Thus, the students' achievement motivation test based on the prior knowledge level of students and students achievement motivation test based on the interaction between the learning model and the prior knowledge level of the students obtained $0.046<0.05$ and $0.044<0.05$. Thus, all of null hypothesis $\left(\mathrm{H}_{0}\right)$ that proposed in this study were rejected, and the results of this study indicated that (1) there were differences in students' achievement motivation between students group who taught by using WBL Model whith the concept of service learning and students group who taught by using TWI model; (2) there were differences in students' achievement motivation between students group who had high, medium, and low prior knowledge; and (3) there was an interaction between the use of WBL model with the concept of service learning and TWI model with prior knowledge levels of students against the students' achievement motivation. The directions of the difference were (1) achievement motivation of students group who taught by using WBL model with the concept of service learning was higher than the achievement motivation of studendts groups who taught by using TWI model; and (2) achievement motivation of students group who had high prior knowledge was higher than achievement motivation of students group who had medium and low prior knowledge.

Table 5. The Results of Two Ways ANOVA Analysis

\begin{tabular}{lrrrrr}
\hline \multicolumn{1}{c}{ Source } & $\begin{array}{c}\text { Type III Sum } \\
\text { of Squares }\end{array}$ & df & \multicolumn{1}{c}{$\begin{array}{c}\text { Mean } \\
\text { Square }\end{array}$} & F & Sig. \\
\hline Corrected Model & $1096.017^{\mathrm{a}}$ & 5 & 219.203 & 12.904 & .000 \\
Intercept & 56451.518 & 1 & 56451.518 & 3323.2 & .000 \\
TWI_WBL & 863.086 & 2 & 431.543 & 25.405 & .000 \\
PRIOR KNOWLEDGE & 71.237 & 1 & 71.237 & 4.194 & .046 \\
TWI_WBL * PRIOR & 113.235 & 2 & 56.617 & 3.333 & .044 \\
KNOWLEDGE & 849.340 & 50 & 16.987 & & \\
Error & 65194.000 & 56 & & & \\
Total & 1945.357 & 55 & & & \\
Corrected Total & $518)$ & & & & \\
\hline
\end{tabular}

a. R Squared $=.562($ Adjusted R Squared $=.518)$

The results of this study indicated that students group who taught by using WBL model with service learning achieved higher achievement motivation compared to students group who taught by using TWI model. This was in line with the opinion of McClelland [5] which stated that the place of education and learning process which experienced by students had a big contribution to the development of students' achievement motivation. The learning process that occurred in WBL model with the concept of service learning was fun, not threatening, encouraging and optimistic, tolerance to the atmosphere of competition, and did not make students worry about failure. In other words, the characteristics of learning designed and implemented using the WBL model had very high similarities to the characteristics of individuals who had high achievement motivation as stated McClelland [5].

The findings of this study were consistent with the findings [5], [19] which shown that WBL was able to increase students' motivation in learning process. 
The learning process in WBL model was similar to the contextual learning process. The students were given the opportunity to design and create products that were contextual in nature and work collaboratively in groups, where in turn, the students groups shown the teacher about the initial design of the object that had been observed and design the product to be made. The process be able to build students' confidence in their ability to solve problems so they motivated theirselves to achieve the achievements [10]. Such learning process was in line with the opinion [21] which stated that learning that started from a contextual problem could lead to cognitive imbalances in students that encourage curiosity and raise many questions, which in turn can increase their achievement motivation.

The results of this study also shown that students group who had high prior knowledge also shown high achievement motivation when compared to students group who had medium and low prior knowledge. According to the forward theory by Willy [22], revealing workers who have high achievement motivation must be able to improve their performance. This was consistent with the findings [7] which shown that the more familiar students into prior knowledge, the higher their intrinsic motivation in the lesson. The findings of this study were also in line with the opinion [23] which stated that prior knowledge was the basis of something that was able to shape one's interests. This was in line with the logic of thinking which stated that to master a new material often required mastery of material at the level below it. That's why Dick \& Carey [19] stated the importance of learning designers to measure the prior knowledge of prospective students of learning products designed before deciding on the material and learning strategies to be used.

The findings of this study also shown that there was an interaction effect between the use of learning models and prior knowledge on students' achievement motivation. This meant that the use of the WBL model with the concept of service learning and the use of TWI was expected appropriately applied to students groups who has high prior knowledge to be able to produce high achievement motivation in students. The results of this study were in line with the findings [16], [24] who concluded that there was an interaction between the use of learning models and prior knowledge of students' learning motivation.

\section{CONCLUSION}

Based on the study results and discussion could be concluded several conclusions as follows (1) there were differences in students' achievement motivation between students group who taught by using WBL model with concept of service learning and students group who taught by using TWI model. The mean of students' achievement motivation which taught by using the WBL model with concept of service learning was significantly higher than the mean of student's achievement motivation which taught by using the TWI model; (2) there were differences in achievement motivation between student groups who had high, medium, and low prior knowledge, where the mean of students group achievement motivation who had high prior knowledge were significantly higher than the mean of students group achievement motivation who had medium and low prior knowledge; and (3) there was an interaction between the use of learning model and prior knowledge of 
students againts students' achievement motivation in order to achieve high achievement motivation, students group who had high prior knowledge could be taught using either the WBL model or the TWI model.

\section{REFERENCES}

[1] J. Andrews and H. Higson, "Graduate Employability, 'Soft Skills' Versus 'Hard' Business Knowledge: A European Study," High. Educ. Eur., vol. 33, no. 4, pp. 411-422, Dec. 2008.

[2] D. A. Sudjimat, Nopriadi, and Yoto, "Study of Implementation of Project Based Learning in Mechanical Engineering Study Program of Vocational High School," J. Phys. Conf. Ser., vol. 1165 , no. 1, p. 12024 , Feb. 2019.

[3] L. Sojow, A. Wajong, and N. Sangi, "Vocational Students' Motivation for Professional Skills," IOP Conf. Ser. Mater. Sci. Eng., vol. 306, no. 1, p. 12072, Feb. 2018.

[4] D. A. Sudjimat, "Mendesain Pembelajaran Kejuruan Berkarakter Pekerja di SMK," J. Teknol. dan Kejuru., vol. 1, no. 3, pp. 83-94, 2014.

[5] D. McClelland, Human Motivation. Cambridge University Press, 1987.

[6] John W. Santrock, "A Topical Approach to Life-Span Development Information Center.ISBN: 0072880163 Copyright year: 2005.” .

[7] E. Purwanto, "Model Motivasi Trisula: Sintesis Baru Teori Motivasi Berprestasi," J. Psikol., vol. 41, no. 2, p. 218 , Dec. 2014.

[8] A. B. R. Shani and J. B. Lau, Behavior in Organization an Experimental Approach. New York: McGraw Hill International Edition, 2009.

[9] C. H. L. Seagraves, M. Osborne, P. Neal, R. Dockrell and A. Boyd,
"Learning in Smaller Companies. Final Report. Educational Policy and Development, University of Stirling," Educ. Policy Dev. Univ. Stirling., 1996.

[10] S. Billett, "Learning through Practice: Beyond Informal and Towards A Framework for Learning Through Practice," in Revisiting global trends in TVET, UNESCOUNEVO, 2013.

[11] F. Abdillah, "Work Based Learning," Bandung, 2014.

[12] B. T. Siswanto, "Pengaruh Model Penyelenggaraan Work-Based Learning Rolling Terpadu terhadap Aspek-Aspek Kualitas Hasil Belajar," J. Pendidik. Teknol. dan Kejuru., vol. 21, no. 1, 2012.

[13] W. W. Gray and B. Albrecht, "Mentoring Youth for Success," Madison, 1999.

[14] R. Wagner, M. Childs, and M. Houlbrook, "Work-based Learning as Critical Social Pedagogy," Aust. J. Adult Learn., vol. 41, no. 3, pp. 314334, 2001.

[15] R. G. Bringle, J. A. Hatcher, and R. E. Mcintosh, "Analyzing Morton' s Typology of Service Paradigms and Integrity," J. Community Serv. Learn., vol. 13, No. 1, no. 2005, pp. 5-15, 2006.

[16] A. Rasyid, "Pengaruh Model Pembelajaran Kooperatif Tipe NHT (Numbered Heads Together) dan Kemampuan Awal terhadap Hasil Belajar Siswa pada Mata Pelajaran Fisika di SMP Negeri 2 Poso," Mitra Sains, vol. 3, no. 1, Apr. 2015.

[17] H. Noelker and E. Schoenfeldt, Vocational Education: Teaching, Planning Curriculum. 1983.

[18] D. A. Sudjimat and M. Romlie, "Karakteristik Pembelajaran Berbasis Proyek Dan Pendekatan Saintifik Pada Matapelajaran Teknologi Pengelasan Busur Manual Di SMK (Suatu Kajian untuk Pengembangan Buku Kerja Siswa)," in Prosiding 
Seminar Nasional Pendidikan Kejuruan Tantangan Pendidikan Kejuruan Abad XXI, 2016, pp. 716725.

[19] W. Dick and L. Carey, The Systematic Design of Instruction, 8th ed. USA: : Pearson Education, Inc, 2015.

[20] H. Sarjono and W. Julianita, SPSS vs LISREL: Sebuah Pengantar, Aplikasi untuk Riset. Jakarta: Salemba Empat , 2011.

[21] W. Dasna, "Innovative Learning Models. Malang: Institute for Education and Learning," Universitas Negeri Malang, 2007.

[22] W. Susilo, Audit SDM: Panduan Komprehensif Auditor dan Praktisi MAnajemen Sumber Daya Manusia serta Pimpinan Organisasi /Perusahaan. Depok: Vorqistatama Binamega, 2011.

[23] S. Handayani, "Hubungan Pengetahuan, Sikap, Minat dan Motivasi Belajar dengan Prestasi Belajar Mata Kuliah KDM I Pada Mahasiswa Semester I Akper Giri Satria Husada Wonogiri," Universitas Sebelas Maret Surakarta, 2008.

[24] M. Iqbal, "Pengaruh Penerapan Strategi Pembelajaran Konstruk tivistik PBP (Pembelajaran Berbasis Proyek) dan Tingkat Kemampuan Akademik terhadap Sikap Siswa SMA kelas X di Malang pada Ekosistem Sungai," Universitas Negeri Malang, 2009. 